\title{
Gender Gaps within Couples: Evidence of Time Re-allocations during COVID-19 in Argentina
}

\author{
Victoria Costoya $^{1} \cdot$ Lucía Echeverría $^{1,2}$ (D) $\cdot$ María Edo $^{1} \cdot$ Ana Rocha $^{1} \cdot$ Agustina Thailinger $^{1}$ \\ Accepted: 30 April 2021 / Published online: 21 May 2021 \\ (c) The Author(s), under exclusive licence to Springer Science+Business Media, LLC, part of Springer Nature 2021
}

\begin{abstract}
Based on a novel survey for Argentina, this paper provides evidence of the changes in time allocation within couples during the COVID-19 emergency. The survey was conducted online during the period of national lockdown in 2020 and collected information on hours allocated to paid work, housework, child care, educational childcare and leisure by both members of the couple before and during the lockdown, as well as socio-demographic characteristics. Our sample consists of 961 couples of which 785 have children. Our results indicate that during the lockdown, despite a reduction in time assigned to paid work and an increase in time spent in unpaid activities for both members of the couple, gender gaps regarding the latter increased. Specifically, while the load of men and women's work for pay became more equitable, women took up a larger proportion of the additional housework and childcare. We found that some factors mitigated (whether the man reduced his hours of work or whether both partners kept on doing so) while others potentiated (whether the woman reduced her hours of work, whether she continued working from home, or whether the couple outsourced housework before lockdown) the changes in the within-couple gender gaps in unpaid activities.
\end{abstract}

Keywords Time allocation · Unpaid work · Within-couple gender gaps · COVID-19

JEL Codes D10 $\cdot \mathrm{D} 13 \cdot \mathrm{J} 16$

\section{Introduction}

In spite of the advances witnessed in recent decades, gender gaps in the labor market have remained considerable (Goldin, 2014; Blau \& Kahn, 2006). The Latin American region is no exception: differences in labor supply, both in the extensive and intensive margins, as well as gaps in wages are large (Marchionni et al., 2019). Recently, the literature has focused on motherhood and intra-household arrangements as the main drivers of the forces behind these gaps (Kleven et al., 2019; Kuziemko et al., 2018; Berniell et al., 2019).

The effects of the recent eruption of the COVID-19 and the subsequent lockdown policies on gender inequalities

Lucía Echeverría

lecheverria@mdp.edu.ar

1 CEDH - San Andrés University, Buenos Aires, Argentina

2 CONICET, University of Mar del Plata, Mar del Plata, Argentina have been an object of discussion (Alon, Doepke, et al., 2020). At the onset of the pandemic, the impact of these policies on gender gaps remained unclear. On the one hand, some studies pointed to the fact that the situation may help reduce gender gaps, given that domestic work became much more visible, at the same time that work flexibility became the norm rather than the exception. On the other hand, given the overload women usually bear regarding childcare and housework (Angelov et al., 2016; Bertrand, 2020), it was likely that the additional childcare and housework due to schools and daycare facilities closure as well as homeschooling would be disproportionally absorbed by women.

The recently emerging empirical evidence showed some mixed results. In the developed world, women were more likely to have stopped paid work during lockdown and the burden on housework and childcare still fell largely on them (Andrew et al., 2020; Carlson et al. 2020; Hupkau \& Petrolongo, 2020; Sevilla \& Smith, 2020). Nevertheless, several studies provided evidence on an increased involvement of men in domestic chores and childcare, which in some cases even led to reductions in the within-couple gender gap 
(Biroli et al., 2020; Mangiavacchi et al., 2020; Sevilla \& Smith, 2020). In Latin America, empirical evidence on the impact of the lockdown associated to COVID-19 is lagging behind. The few studies exploring the topic found in general that a disproportionate amount of the additional time imposed by the lockdown was being absorbed by women (Romero \& Reys, 2020; Wanderley et al., 2020; Dobrée \& Cora, 2020). However, the evidence for the Latin American region does not focus on within-couple time arrangements.

Analyzing the impact of lockdown policies through the lens of the couple, and not only through individuals' allocation of time, is of paramount importance. As stated before, recent literature pointed to motherhood and intra-household arrangements as the main drivers in the labor market gender gap. This implies that, for individuals living in couples, the allocation of time across different activities is generally the result of a bargaining process that may adopt different forms (Chioda, 2016). For instance, Goldin (2006) distinguished between couples in which labor force decisions (and therefore, housework and childcare allocations of time) are made fully jointly and those in which one of the members of the couple (generally the woman) optimizes their time allocation taking their partner's labor market decisions as given.

This paper explores the changes in the allocation of time within couples with and without children, focusing on paid work, housework, childcare and educational childcare, as well as leisure time. We collected data on a sample of Argentinean couples with and without children and asked information about time devoted by each member of the couple to each activity (paid work, housework, childcare, educational childcare and leisure) before and during the lockdown. Argentina provided a particularly interesting scenario to explore time re-allocations within the couple because of the length of the national lockdown policies (a total of 103 days at the time our survey was implemented), which included school and day-care closure and homeschooling. This compares to few other countries around the world, such as Perú, Ecuador, Colombia, Paraguay, India, and Bolivia. ${ }^{1}$

We first analyzed the within-household gender gap for each activity before and during the lockdown, measured as the difference between the number of hours spent on each activity by women and men. We were able to compute these measures directly from our survey, exploiting the observation of allocation of time for both members of the couple, before and during the lockdown. Second, we investigated factors associated changes in the within-couple gender gap, focusing on housework, childcare, and educational childcare.

Our results indicated that on average men allocated more time to paid work and less time to housework, childcare, and

\footnotetext{
1 https://www.lanacion.com.ar/el-mundo/coronavirus-los-paisescuarentenas-mas-largas-pandemia-nid2430138/.
}

educational childcare than women before lockdown. During the lockdown there was a reduction in time assigned to paid work and an increase in time spent in housework and childcare for both members of the couple. However, the within-couple gender gap showed opposite changes during lockdown: while the gap in paid work decreased, the gap in housework and childcare increased. That is, even though there was an equalizing effect in terms of paid work, the additional time spent by couples in unpaid activities was disproportionally carried out by women. In particular, the largest increase found corresponds to time allocated to educational childcare associated to homeschooling, followed by the gap in housework. Additionally, our analysis provides some interesting insights that may shed light on the factors related to the changes in the within-couple gender gaps in unpaid work during the lockdown. Our evidence shows that some factors mitigated (whether the man reduced his hours of work or whether both partners kept on doing so) while others potentiated (whether the woman reduced her hours of work, whether she continued working from home, or whether the coupled outsourced housework before lockdown) the changes in the within-couple gender gaps in unpaid activities.

This paper contributes to the emerging evidence and discussion on the impact of COVID-19 and lockdown policies on time use patterns. In particular, it aims at filling the existing knowledge gap in terms of the differential effects of the pandemic on time use across gender in developing countries.

\section{Related Literature}

Since the beginning of the pandemic, ${ }^{2}$ there has been a growing number of studies analyzing different impacts on family life (Alon, Doepke et al., 2020; Andrew et al., 2020; Biroli et al., 2020; Mangiavacchi et al., 2020).

Empirical evidence documenting the impact of lockdowns on men and women's allocations of time for developed countries started to emerge. Based on evidence from time data surveys, Carlson et al. (2020) for the US, and Andrew et al. (2020), Sevilla and Smith (2020), and Hupkau and Petrolongo (2020) for the UK, found that women were more likely than men to have stopped working since the beginning of the pandemic. In cases where they continued to work, women fared a larger portion of the additional housework and childcare activities. ${ }^{3}$ Other studies highlighted the special vulnerability of some groups, for example, single

\footnotetext{
2 The World Health Organization classifies the start of the pandemic as of March $1^{\text {st }}$.

${ }^{3}$ For a compared analysis on developed countries please refer to Adams-Prassl et al. (2020); Biroli et al. (2020); Galasso et al. (2020).
} 
and unemployed mothers (Alon, Doepke, et al., 2020; Alon, Kim, et al., 2020; Zhou et al., 2020), working mothers with young children (del Boca et al., 2020), and less educated mothers (Farré et al., 2020). However, many of these studies reported an important increase the time devoted by the father to domestic work (Biroli et al., 2020), which in some cases could even have led to an increase in children's wellbeing (Mangiavacchi et al., 2020) and contribute to the reduction in the within-household gender childcare gap (Sevilla \& Smith, 2020). This increase in fathers' involvement during the crisis may be seen as a window of opportunity for shifting existing social norms towards gender equality.

Moreover, another strand of literature has explored the potential effects of lockdown policies on time allocation based on data using Time Use Diaries collected before the pandemic. For instance, Hamermesh (2020) focused on the impact of a simulated lockdown on wellbeing using the 2012-2013 American Time Use Survey while GiménezNadal et al. (2020) found differentiated effects on time allocation of men and women based on data for the US and the UK.

In contrast with the growing literature in the developed world, research on the impact of COVID-19 lockdowns for women's lives and intra-household arrangements in Latin America is lagging behind. Providing country-based evidence is of paramount importance given the difference in terms of cultural and social norms and institutional frameworks between developed and developing countries. ${ }^{4}$ Romero and Reys (2020) ran a survey on Lima's (Peru) population in order to analyze the economic impact of the lockdown together with the effects of other measures taken by the government due to the pandemic. Results suggested that there was a higher participation of men on domestic activities, especially in the middle and upper classes, although this was only observed for the purchasing of food and basic supplies. Based on a survey carried out during the confinement in Bolivia, Wanderley et al. (2020) pointed out that women showed greater depression, anxiety, stress, and psychological impact than men. Moreover, they suggested that people who reported that household chores were not shared with a partner during quarantine were twice as likely to have been affected on these dimensions. Dobrée and Cora (2020) used a Time Use Survey carried out in Paraguay in 2016 to predict possible consequences of confinement measures, and indicated the possibility of an increase in the burden of care on women, who already spent twice as much time as men on domestic tasks. Along this line, ECLAC (2020) warned about a possible exacerbation of the care crisis that is already affecting women in Latin America and the Caribbean, as

\footnotetext{
${ }^{4}$ Previous studies analyze the gendered distribution of time in Latin America (Campaña et al. 2018) before the pandemic.
}

they usually spend three times as much as men on unpaid domestic and care work each day. This effect is magnified in lower income households, given that they usually tend to have more dependent people to look after. ${ }^{5}$ In this same line, UN Women, together with UNICEF and Option Consultants (2020), ran a survey on childhood, gender, and time use in the context of the pandemic for Uruguay, and found a reduction in the relative gender gap in unpaid work on both high and medium educational levels. The opposite was found in low educational levels, as men in this segment were the only ones who did not increase the burden of unpaid work in the context of COVID-19. They also pointed out that female work decreased most as a result of the pandemic and highlighted that women were still shouldering most of the household chores. Regarding Argentina in particular, some preliminary evidence suggested that woman were taking on the larger share of the additional burden in unpaid activities posed by the lockdown. 67

The present work contributes to the emerging evidence on the impact of COVID-19 and the lockdown policy on time use patterns in developing countries. We provide novel data covering time allocation patterns in paid work, housework, and childcare for both members of the couple, before and during lockdown. In this way, we are able to provide evidence of within-couple re-allocation of time during the pandemic. The length of the lockdown in Argentina (more than 103 days when the survey was implemented), provided an adequate setting to explore intra-household rearrangements regarding time allocation.

\section{Data}

\section{COVID-19 and Lockdown in Argentina}

As the rest of the Latin America region, Argentina was hit by the pandemic later than China and the European countries. The containment experiences of these countries served the region as an example to apply preventive measures earlier than Spain or Italy, which were surprised by the exponential increase in cases. Despite Brazil being the first country in the region to announce the first coronavirus case in later February, Argentina reported the first death in the region due to COVID-19 on March 7th, four days after reporting its first case.

\footnotetext{
${ }^{5}$ For more data on the care crisis in the region see ECLAC (2019).

${ }^{6}$ See: https://unciencia.unc.edu.ar/sociedad/mujeres-en-cuarentenacuidadoras-de-tiempo-completo-y-sobrecarga-de-trabajo/, https:// generoytrabajo.com/2020/04/06/coronavirus-clave-genero/ and http:// www.bdigital.cesba.gob.ar/handle/123456789/467/.

7 In addition, a study for Argentina investigates the impact of COVID-19 on domestic violence (Carreras et al. 2020).
} 
On March 16th, the national government announced the closing of schools at all levels, affecting more than 10 million students, as well as the closure of borders. The measure also prohibited households from relying on external help for domestic chores, an extended practice in Argentinean high and middle class families. By March 19th, the first lockdown measure was taken; the government decided to implement a national confinement of the population, declaring an official quarantine. The lockdown policies continued throughout the country during all of 2020, although with different degrees of flexibility. The Metropolitan Area of Buenos Aires, which concentrates almost $40 \%$ of the country's population, remained in a tight lockdown (Aislamiento Social, Preventivo y Obligatorio) until November 2020, while in the rest of the country a more flexible regime prevailed (Distanciamiento Social, Preventivo y Obligatorio), with the exception of some particular regions or periods following sharp increases in the spread of the disease. ${ }^{8}$ Nevertheless, it is important to note that even under the more flexible schemes, both schools and domestic help continued to be excluded from the allowed activities.

By the end of July (when our survey took place), Argentinians had been in lockdown for more than 100 days and the removal of restrictions was still not in the horizon. The country was among those with the strongest government measures across the world (Hale et al. 2020). The prolonged lockdown led to a sharp increase in unemployment, time spent at home for all individuals, remote work for some adults, and online schooling for children.

\section{Survey}

The data were collected on a sample of Argentinean families between June 12nd and July 25th 2020, reaching 961 couples during the period of national lockdown, of which 785 had children and reported positive childcare time. The ad-hoc survey was implemented online, and it was voluntary and anonymous. It was aimed at tracking if, and to what extent, there were changes in the allocation of time within couples associated with the COVID-19 lockdown, by comparing the situation before and during the lockdown.

We designed the questionnaire to gather information on hours dedicated to the following types of activities before and during the lockdown: (a) paid work; (b) housework (including general chores such as cooking, cleaning, shopping, etc.); (c) children care (including general activities such as playing, supervising, bathing, etc.); (d) educational childcare (including all activities related to the remote learning and homeschooling imposed by the lockdown); and (e)

\footnotetext{
8 https://www.boletinoficial.gob.ar/detalleAviso/primera/230245/ 20200608/.
}

leisure. The survey respondents were women, who were asked how many hours per day they allocated to these activities before and during the lockdown, as well as the hours allocated by their partners. ${ }^{9}$ This follows the approach of Sevilla and Smith (2020) and del Boca et al. (2020). Given that we asked information about time devoted to different activities by both members of the couple, our data allowed us to consider the perceived allocation of time within the couple. $^{10}$

The survey collected information on women's sociodemographic variables including age, level of education (primary, secondary and higher education), and work arrangements (working from home or from the office during lockdown), as well as household-level characteristics, such as number and age of children, whether the household outsourced domestic chores by relying on a domestic employee before the lockdown, and region of residence (Northern, Southern, Central Region, and the Metropolitan Area of Buenos Aires). Survey respondents had to selfreport to which income quintile their household belonged. Quintiles were defined ex-ante, based on the national income distribution cut-offs, estimated using the Argentinean Time Use Survey carried out by the National Statistics Office in Argentina in 2013 (INDEC). Lastly, we included questions on previous and current employment status for both members of the couples.

Table 1 shows descriptive statistics of relevant variables associated with the lockdown and socio-demographic variables used in the empirical analysis presented in the next Section. On average, the women respondents were 40 years old and almost $10 \%$ of them had only primary school level, while almost half of them had finished high school. In our sample, $18.3 \%$ of women did not have children. Of those who had, $26.2 \%$ had only one child, $27.1 \%$ two children, $18.8 \%$ three and around one out of ten had four or more.

More than two thirds of the families in our sample lived in the Central Region of the country, around 15\% in the Metropolitan Area of Buenos Aires, and almost 10\% and 5\% in the Northern and Southern regions respectively. Almost half of the surveyed families $(48.2 \%)$ belonged to the first two quintiles of the income distribution.

\footnotetext{
9 See Appendix A for details regarding the questions included in the survey.

${ }^{10}$ It is important to note that since we used a stylized questionnaire rather than time use diaries, our data is subject to measurement error (Kan and Pudney 2008). Furthermore, the fact that only one member of the couple responded to the survey could also raise the concern on whether there is a potential gender bias in reported hours. However, Andrew et al. (2020) provide evidence on the fact that the gender of the main respondent is not associated to systematic differences on gender gaps for reported time use.
} 
Table 1 Descriptive statistics

\begin{tabular}{llc}
\hline Variables & Mean & S.D \\
\hline Woman's age & 40.30 & 10.48 \\
Woman has secondary education & $44.0 \%$ & - \\
Woman has higher education & $46.4 \%$ & - \\
Families without children & $18.3 \%$ & - \\
Families with 1 child & $26.2 \%$ & - \\
Families with 2 children & $27.1 \%$ & - \\
Families with 3 children & $18.8 \%$ & - \\
Families with +4 children & $9.6 \%$ & - \\
Northern Region & $9.6 \%$ & - \\
Central Region & $70.1 \%$ & - \\
Southern Region & $4.9 \%$ & - \\
Buenos Aires City & $15.4 \%$ & - \\
Low income family & $48.2 \%$ & - \\
Both women and men work during lockdown & $57.8 \%$ & - \\
Change in hours of work (before and during lockdown) - man & -1.51 & 3.31 \\
Change in hours of work (before and during lockdown) - woman & -1.16 & 3.36 \\
Woman working from home during lockdown & $31.9 \%$ & - \\
Family relied on a domestic employee before lockdown & $23.8 \%$ & - \\
$\mathrm{N}$ & 961 & \\
\hline
\end{tabular}

Although in the majority of families included in our sample both members of the couple continued working during lockdown (57.8\%), both men and women suffered a reduction in the hours of paid work. In addition, $31.9 \%$ of women reported working from home during lockdown. Furthermore, almost a quarter of families in our sample had relied on a domestic employee before the lockdown to perform certain household chores, and in some cases childcare activities, an extended practice among middle and upper classes in Latin America.

Even though the survey was conducted without a sampling strategy, the design was aimed at meeting relevant household-level socio-demographic quotas in order to be in line with national statistics reported by the National Statistics Office in Argentina (INDEC). Table B.1 in Appendix B reports the comparison of key variables with the nationally representative Argentinean Time Use Survey. Our results were in line with national statistics in several relevant sociodemographic characteristics, such as the presence of children, distribution of households across income quintiles, average number of children, proportion of families of different sizes, and average women's age. While the proportion of households living in the Southern and Central regions mimicked the national average, our survey represented slightly more households from the Metropolitan Area of Buenos Aires than those from the Northern Region. In addition, our sample was composed of relatively more educated women and a higher proportion of them were employed. In relation to this, and comparing average time use, women in our sample worked relatively more hours per week and allocated more hours per day to education childcare. However, the average hours of housework and childcare devoted by women and men were similar to national figures.

\section{Results}

In this section we analyze the changes in the distribution of time within couples with and without children, focusing on five activities: paid work, housework, childcare, educational childcare, and leisure. We first analyze the within-household gender gap for each activity before and during the lockdown, measured as the difference between the number of hours spent by women and men. We were able to compute these measures directly from our survey, exploiting the observation of allocation of time for both members of the couple, before and during the lockdown. Secondly, we investigate factors associated with changes in the within-couple gender gap, focusing on each unpaid activity (housework, childcare, education support of children).

\section{Descriptive Results}

Table 2 shows the average daily time allocation of each member of the couple and the within-couple gender gaps before and during lockdown (Panel A and B respectively). We defined the within-couple gaps for each activity as the 
Table 2 Daily time allocation within couples before and during lockdown

\begin{tabular}{|c|c|c|c|c|c|c|c|c|c|c|c|}
\hline & \multicolumn{5}{|c|}{$\begin{array}{l}\text { Panel (A): } \\
\text { Before Lockdown }\end{array}$} & \multicolumn{5}{|c|}{$\begin{array}{l}\text { Panel (B): } \\
\text { During Lockdown }\end{array}$} & \multirow{3}{*}{$\begin{array}{l}\text { Panel (C): Difference } \\
\text { Within-Couple Gap Change }\end{array}$} \\
\hline & \multicolumn{2}{|c|}{$\begin{array}{l}\text { Women (daily } \\
\text { hours) }\end{array}$} & \multicolumn{2}{|c|}{$\begin{array}{l}\text { Men (daily } \\
\text { hours) }\end{array}$} & \multirow{2}{*}{$\begin{array}{l}\text { Average } \\
\text { Within-Couple } \\
\text { Gap } \\
\text { (i) }\end{array}$} & \multicolumn{2}{|c|}{$\begin{array}{l}\text { Women (daily } \\
\text { hours) }\end{array}$} & \multicolumn{2}{|c|}{$\begin{array}{l}\text { Men (daily } \\
\text { hours) }\end{array}$} & \multirow{2}{*}{$\begin{array}{l}\text { Average } \\
\text { Within-Couple } \\
\text { Gap } \\
\text { (ii) }\end{array}$} & \\
\hline & Mean & S.D & Mean & S.D & & Mean & S.D & Mean & S.D & & \\
\hline Paidwork & 4.75 & 3.28 & 6.58 & 2.96 & $-1.83 * * *$ & 3.59 & 3.49 & 5.08 & 3.46 & $1.48 * * *$ & $0.35^{*}$ \\
\hline Housework & 3.73 & 2.46 & 1.62 & 1.97 & $2.11 * * *$ & 4.42 & 2.46 & 1.99 & 2.00 & $2.44 * * *$ & $0.32 * * *$ \\
\hline Childcare & 4.34 & 3.27 & 1.84 & 2.28 & $2.50 * * *$ & 4.78 & 3.36 & 2.13 & 2.45 & $2.65 * * *$ & 0.15 \\
\hline Educ. childcare & 2.48 & 2.43 & 1.04 & 1.71 & $1.44 * * *$ & 3.27 & 2.68 & 1.28 & 1.93 & $1.98 * * *$ & $0.54 * * *$ \\
\hline Leisure & 2.10 & 1.87 & 2.28 & 2.00 & $-0.17 * *$ & 2.52 & 2.27 & 2.69 & 2.35 & $-0.18^{*}$ & -0.01 \\
\hline
\end{tabular}

Average number of hours devoted by each member of the couple to each activity and average within-couple gap. Within-couple gaps are defined as daily hours allocated by the woman to a given activity minus hours allocated by the man. Difference in the average within-couple gap for each activity is calculated as the within-couple gap during the lockdown minus the within-couple gap before the lockdown. Columns (i), (ii) and (iii) report t-tests on the equality of means

* $\mathrm{p}<0.05, * * \mathrm{p}<0.01, * * * \mathrm{p}<0.001$

hours allocated by the woman to a given activity minus the hours allocated by her male partner to the same activity (paid work, housework, childcare, educational childcare, and leisure).

Panel (A) shows that on average, within-couple gender gaps were large in all activities before lockdown. In fact, women spent almost 2 hour of paid work less than men per day while performing 2 more hours of domestic chores. Furthermore, childcare showed the largest difference, with women dedicating 2.3 more hours per day than men. Additionally, women allocated 1.3 more hours than men to educational childcare every day. All of these gaps were statistically significant and in line with results from the Argentinean Time Use Survey implemented in 2013, which indicated that women devoted on average twice the time to unpaid work than men, including housework and childcare (INDEC, 2020). Our evidence is also consistent with previous studies for other Latin American countries documenting that men spent more time in paid work, while women were burdened with the bulk of domestic chores and childcare (Campaña et al. 2018; Canelas \& Salazar, 2014).

The lockdown implied re-allocations in the distribution of time within the couple, as reported in Panel (B) of Table 2. In particular, while on average time assigned to paid work decreased for both couple members, unpaid work (including domestic chores and child-related activities) increased for both. Regarding paid work, men reduced weekly hours by 7.5 hour and women by 5.8 hour. In terms of unpaid work, each week couples endured an additional 5.3 hour of housework, 3.7 hour of childcare and 5.2 hour of educational childcare.

However, these changes in allocation of time within couples were not evenly distributed across gender. Panel (C) of Table 2 reports the within-couple gap change as the difference in the gaps during and before lockdown for each activity. Surprisingly, while the within-couple gender gap in paid work decreased, the within-couple gap in unpaid activities increased.

On the one hand, given that the reduction in working hours was larger for men than for women, the gender gap in paid work went down. While before the lockdown the within-couple gender gap in paid work amounted to almost 2 hour per day, during lockdown it decreased to 1.5 hour. This implied a half an hour reduction in the paid work gender gap within couples, which was statistically significant. On the other hand, the within-couple gender gap regarding unpaid activities increased. Educational support showed the largest increase by around half an hour, followed by a 20-min rise in housework. Both of these increases in the within-couple gender gap are statistically significant. Conversely, childcare showed a small increase in the gap, and this difference was not statistically significant. However, it is important to bear in mind that childcare showed the largest gaps both before and during lockdown. All in all, the within-couple gender gap in unpaid work increased by 4.3 hour per week.

Our results indicate that the lockdown led to a reduction in paid work and an increase in time spent in unpaid activities for both men and women. However, these changes were not equally distributed across gender. While men reallocated time from paid to unpaid work, women increased total work hours by around one hour each day. This implied that the lockdown had opposite effects on the existing within-couple gender gap in the allocation of time. On the one hand, the lockdown was associated with an equalizing effect in terms of paid work: even though during the lockdown men still spent more time than women on paid work, this within-couple gap was reduced. On the other hand, the within-couple gender gap regarding unpaid activities became even more 
Table 3 Regressions on withincouple gender gap changes

\begin{tabular}{|c|c|c|c|c|c|c|}
\hline & \multicolumn{2}{|l|}{ Housework } & \multicolumn{2}{|l|}{ Childcare } & \multicolumn{2}{|c|}{$\begin{array}{l}\text { Educational child- } \\
\text { care }\end{array}$} \\
\hline & (1) & (2) & (3) & (4) & $(5)$ & (6) \\
\hline Man and woman working & $\begin{array}{l}0.055 \\
(0.219)\end{array}$ & $\begin{array}{l}0.0141 \\
(0.221)\end{array}$ & $\begin{array}{l}-0.282 \\
(0.258)\end{array}$ & $\begin{array}{l}-0.310 \\
(0.259)\end{array}$ & $\begin{array}{l}-0.382^{\dagger} \\
(0.207)\end{array}$ & $\begin{array}{l}-0.400^{\dagger} \\
(0.207)\end{array}$ \\
\hline Working from home-woman & $\begin{array}{l}0.363 \\
(0.233)\end{array}$ & $\begin{array}{l}0.220 \\
(0.258)\end{array}$ & $\begin{array}{l}0.655^{*} \\
(0.285)\end{array}$ & $\begin{array}{l}0.645^{*} \\
(0.316)\end{array}$ & $\begin{array}{l}0.753 * * \\
(0.228)\end{array}$ & $\begin{array}{l}0.697 * * \\
(0.252)\end{array}$ \\
\hline Change in hours of work-man & $\begin{array}{l}0.053^{\dagger} \\
(0.028)\end{array}$ & $\begin{array}{l}0.057^{\dagger} \\
(0.029)\end{array}$ & $\begin{array}{l}0.085^{*} \\
(0.033)\end{array}$ & $\begin{array}{l}0.086 * \\
(0.034)\end{array}$ & $\begin{array}{l}0.057 * \\
(0.027)\end{array}$ & $\begin{array}{l}0.055^{*} \\
(0.027)\end{array}$ \\
\hline Change in hours of work-woman & $\begin{array}{l}-0.099 * * \\
(0.032)\end{array}$ & $\begin{array}{l}-0.102 * * \\
(0.033)\end{array}$ & $\begin{array}{l}-0.089 * \\
(0.038)\end{array}$ & $\begin{array}{l}-0.093^{*} \\
(0.039)\end{array}$ & $\begin{array}{l}-0.056^{\dagger} \\
(0.031)\end{array}$ & $\begin{array}{l}-0.068^{*} \\
(0.031)\end{array}$ \\
\hline From home $*$ change hs.—woman & $\begin{array}{l}0.010 \\
(0.063)\end{array}$ & $\begin{array}{l}0.001 \\
(0.0640)\end{array}$ & $\begin{array}{l}-0.133^{\dagger} \\
(0.074)\end{array}$ & $\begin{array}{l}-0.118 \\
(0.075)\end{array}$ & $\begin{array}{l}-0.031 \\
(0.059)\end{array}$ & $\begin{array}{l}-0.022 \\
(0.060)\end{array}$ \\
\hline Domestic Employee & $\begin{array}{l}0.645 * * \\
(0.230)\end{array}$ & $\begin{array}{l}0.450^{\dagger} \\
(0.257)\end{array}$ & $\begin{array}{l}-0.050 \\
(0.281)\end{array}$ & $\begin{array}{l}-0.078 \\
(0.315)\end{array}$ & $\begin{array}{l}0.525^{*} \\
(0.225)\end{array}$ & $\begin{array}{l}0.400 \\
(0.251)\end{array}$ \\
\hline Controls & No & Yes & No & Yes & No & Yes \\
\hline Observations & 961 & 961 & 785 & 785 & 785 & 785 \\
\hline R-squared & 0.031 & 0.040 & 0.039 & 0.048 & 0.047 & 0.063 \\
\hline
\end{tabular}

"Housework" is the within-couple gender gap change in hours allocated to housework; "Childcare" is the within-couple gender gap change in hours allocated to childcare; "Educational Childcare" is the withincouple gender gap change in hours allocated to educational support. All changes compare the within-couple gender gaps before and during lockdown. Within-couple gender gaps are defined as hours allocated to the activity by the woman minus hours allocated to the same activity by the man. For "Housework" all couples are included, for "Childcare" and "Educational Childcare" only couples with children are included. The set of controls is: woman's level of education, woman's age, an indicator if the family belongs to the lowest two income quintiles, number of children in the household and regional variables. Standard errors in parenthesis. Full set of estimates are reported in Table B.3 of Appendix B

${ }^{\dagger} \mathrm{p}<0.1, * \mathrm{p}<0.05, * * \mathrm{p}<0.01$ pronounced during lockdown than before. The additional time spent by couples in unpaid activities was disproportionally carried out by women, who performed $65.1 \%$ of the additional hours of housework, $60.3 \%$ of the additional childcare, and $76.7 \%$ of the additional educational support activities.

When considering total hours of work (that is, combining paid work with housework and childcare), the evidence showed that women worked more than men before lockdown and that this gap increased as of the pandemic. In fact, while women outworked men by 4.22 hour before lockdown, this difference enlarged to 5.6 hour during the confinement. This change was statistically significant to $1 \%$.

\section{Empirical Analysis}

Our evidence suggests that the within-couple gender gaps in hours allocated to paid and unpaid work evolved in opposite directions. While the former showed a reduction during lockdown, the latter showed an increase. Exploring the factors related to these opposite changes is relevant since it may reveal intra-household negotiations as well as shed light on the bargaining power of couple members. Unfortunately, our data did not allow us to explore the possible mechanisms that may have been associated with changes in the allocation of time to paid work, such as work hours' reduction, furlough, or resignation, among others. In contrast, gaps in leisure time showed negligible changes during lockdown and this difference was not statistically significant. Therefore, in this section we focus on exploring the changes in the withincouple gender gaps on unpaid activities.

We performed a difference-in-difference regression analysis on the within-couple change in the allocation of time on unpaid activities. This strategy allowed us to control for unobserved household-level heterogeneity. We used as dependent variables the changes in the within-couple gender gap in hours allocated to unpaid activities: (i) housework, (ii) childcare, and (iii) educational support activities. The change in the within-couple gender gap was defined as:

$w c$ gap $_{\text {change }}=w c$ gap $_{i j 1}-w c \operatorname{gap}_{i j 0}$

That is, the dependent variable measures the difference between the within-couple gender gap measured in hours of household $i$ in activity $j$ (housework, childcare and educational support) during lockdown $\left(w_{c g a p} p_{i j 1}\right)$ and before 
lockdown $\left(\right.$ wcgap $\left._{i j 0}\right)$. Note that Table 2 shows the average values of these variables for each activity: Panel (C) shows the average value of wcgapchange $_{j}$, while columns (i) and (ii) represent the average gaps before $\left(w_{c g a p}{ }_{j 0}\right)$ and during $\left(w_{c g a p}\right)$ the lockdown, respectively.

Let us illustrate this with an example. Suppose that wcgap $_{1 h w 0}=2$ and $\operatorname{ccgap}_{1 h w 1}=3$, with $j=h w$, then in household 1 the woman performed 2 more hours of housework than her partner before lockdown and carried 3 more hours than her partner during lockdown. In this case, wcgapchange $_{1 h w}$ equals 1 , meaning that the within-couple gender gap in housework increased by an hour during lockdown. Intuitively, an increase in the within-couple gender gap change ( wcgapchange $_{i j}$ ) would capture the increase in the allocation of time of the woman in the household to a certain activity during lockdown relative to her partner, compared to the difference that existed between partners before the lockdown.

To explore the factors associated to this within-couple gap changes we estimate the following OLS regression:

wc gap change $e_{i j}=\alpha+\beta X_{i}+\gamma W_{i}+u_{i}$

where $\mathrm{X}$ is a vector of relevant variables associated with the occupational status and job changes of the members of the couple. In particular, we included an indicator variable that showed whether both partners continued working during lockdown, if the woman worked from home during lockdown, and the change in hours of paid work for men and women. We also included an interaction term to explore if the change in hours of work for woman generated an additional effect when both members of the couple worked from home. Further, we added an indicator that showed if the couple relied on domestic help before the lockdown. The vector W includes a set of controls: woman's level of education (primary, secondary or higher education), woman's age, an indicator of whether the family belonged to the lowest two income quintiles, the number of children in the household and region of residence (Northern, Southern or Central Region, and the Metropolitan Area of Buenos Aires).

Table 3 presents the results of the OLS regressions on the three outcomes of interest: changes in the within-couple gender gap in the allocation of hours to (i) housework; (ii) childcare; and (iii) educational childcare activities. Columns (1), (3) and (5) include the set of variables of interest, while Columns (2), (4) and (6) control for socio-demographic characteristics at the household level. Full set of estimates are reported in Table B. 2 of Appendix B. In addition, we present a robustness check using post-stratification weights through raking techniques based on national values of a set of key socio-demographic variables (level of education of the woman, income quintile, presence of children and region of residence). Regression results are reported in Table B.3 of Appendix B.

Results show some interesting insights that may shed light on certain factors related to the changes in the withincouple gender gaps in housework, childcare, and educational childcare during the lockdown. In terms of housework, the most relevant features are the change in hours of paid work for women and men. In households where the man reduced the hours of work during lockdown, the change in the within-couple gender gap in housework was lower than for the rest of households. This means a reduction in the within-couple gender gap change, which implies that there was an increase in the time spent in housework activities by men during lockdown relative to their partners, compared to the gap existing before the lockdown.

On the other hand, a reduction in women's hours of paid work during the lockdown meant an increase in the within-couple gender gap. In addition, in households that outsourced housework before the lockdown and had to go without help, the additional hours dedicated to housework were largely absorbed by women. In fact, the within-couple gender gap change in housework in households that had a domestic employee before the lockdown was almost one hour larger than in households that never outsourced household chores. In other words, the gender gap regarding housework -which was already large- increased even more in families where a domestic employee had been present before the lockdown.

Regarding child-related activities, a similar effect was found for the change in hours of work of both partners. In the cases where men reduced their work time, there was a reduction in the change of gender gaps in childcare and educational activities, although the effect was almost double in childcare activities (around 1 hour). If women reduced their time allocated to paid work, the gender gap change increased, but the effect was lower in the case of educational activities. Further, two features stood out. On the one hand, in families where the woman worked from home, there was an increase in the within couple change in gender gap. However, no additional effect was found if women reduced their hours of work but worked from home. On the other hand, the change in the gender gap in educational childcare activities was reduced in the cases in which both members of the couple continued working during lockdown, meaning that men increased (or women decreased) the allocation of time to educational activities during lockdown relative to their partners, compared to the gender gap before lockdown.

To sum up, the time re-allocation within couples during COVID-19 seems to be closely related to the occupational status of partners and the possibility of working from home, and to a lesser extent, whether the family outsourced housework before the lockdown. For the three activities considered, there was a reduction in the gender gap change in 
those families where the man reduced his work time or the woman increased her work time. In addition, the gap change for educational childcare decreased in those cases in which both members of the couple continued working during lockdown. Conversely, for childcare and educational activities, there was an increase in the gap change when the woman worked from home. Lastly, larger gender gaps in housework activities were also found for households who outsourced household chores before lockdown.

Our results are in line with evidence for the UK (Sevilla \& Smith, 2020), Italy (del Boca et al., 2020) and Spain (Farré et al., 2020), documenting that women bore most of the burden of household tasks and childcare during the COVID-19 emergency. Also, our evidence, of a more equal allocation of time when men reduced their work time during lockdown, is similar to the results found in Sevilla and Smith (2020) and Mangiavacchi et al. (2020) for Italy. Therefore, in general this evidence points to a similarity in the changes experienced in gender gaps in the developed and developing world.

\section{Conclusion}

Despite strong advances in the role of women in the public sphere in the last decades, gender gaps have remained considerable in terms of labor force participation, wages, and the occupation of hierarchical positions by women. Motherhood and intra-household arrangements have been pointed to recently in the literature as the last hurdle in achieving gender equality. The Latin American region is not an exception in this regard.

The recent eruption of the COVID-19 pandemic as well as its subsequent lockdown policies may have had an impact on these gender imbalances, especially within couples, given the additional workload posed by the increase in housework, childcare, and educational support children need for online schooling. At the onset of the pandemic, the effect was not clear. On the one hand, gender gaps could be reduced in as much as domestic work became more visible and flexible remote work arrangements became the norm rather than the exception. On the other hand, it is also possible that gaps increase if the additional workload were to be distributed unevenly across genders. Empirical evidence for developed countries showed some mixed evidence in this regard, with findings in both the disproportionate increase of workload on women and a higher involvement of fathers. For the Latin American region, the still scarce evidence pointed more into the direction of increasing gaps.

This paper contributes to the literature by presenting novel evidence of perceived within-couple changes in the allocation of time to paid work, housework, childcare, educational childcare, and leisure as a consequence of the eruption of COVID-19 and lockdown policies for Argentina. Our results are in line with previous studies for developed countries in terms of women bearing most of the burden of housework and childcare during the COVID-19 lockdown. Restrictions imposed by the labor market may help reduce gender gaps within the couple by increasing father's involvement.

According to our results, within-couple gender gaps before lockdown were large, with men performing more paid work than their partners and women carrying out more of the unpaid load. With the lockdown following the eruption of COVID-19, these within-couple gender gaps changed in opposite directions. On the one hand, gaps regarding paid work seem to have narrowed mildly, following a larger reduction in hours worked by men than by women. However, this equalization was not translated into a more even distribution of unpaid work within couples. On the contrary, results showed that the gap in housework and childcare seems to have increased. In particular, the largest withincouple gender gaps increases were found in provision of educational childcare related to remote learning activities and household chores. Within-couple gender gaps regarding childcare did not seem to have changed significantly, but it is important to bear in mind that childcare still showed the largest gap among unpaid activities. All of these effects were statistically significant. Several factors were associated with these changes in within-couple gender gaps on unpaid activities. The change in the within-couple gender gap increased when women reduced the time allocated to paid work during lockdown and when they kept on working from home. Conversely, it narrowed if the man reduced his work time, or if both partners kept on working during lockdown in the case of educational activities. Moreover, the change in the gap was larger for those households relying on a domestic employee before the lockdown.

The overall effect of COVID-19 and lockdown in Argentina on within-couple gender gaps remain unclear. While there was a reduction of within-couple gender gaps in paid work, there was also an increase in within-couple gaps of unpaid activities. If the former is more tied to external factors to the couples, and if the latter reflects an underlying bargaining process and time arrangements within the couple, the negative effect on gender gaps may prevail in the long run. Next steps in research should focus on evaluating long terms effects of the lockdown on time allocation within the family. 


\section{Appendix A}

\section{Survey Questions}

The survey included a set of socio-demographic questions as well as questions regarding time allocation before and during the lockdown. These questions were answered by women living with a partner. Each woman answered timeuse questions regarding both their own time as well as their partner's. In what follows we reproduce the survey questions (translated to English):

\section{Section A-Socio-Demographic Questions}

1. Age

2. Province

3. Which is the highest level of education you finished?
a. Primary School
b. Secondary School
c. Tertiary level
d. University degree or higher

4. In which of these income brackets do the income of your household lie?
a. $\$ 0$ through $\$ 20.000$
b. $\$ 20.000$ through $\$ 30.000$
c. $\$ 30.000$ through $\$ 45.000$
d. $\$ 45.000$ through $\$ 70.000$
e. $\$ 70.000$ or more

5. Which is your main occupation?
a. I do not work
b. I have a formal job
c. I have an informal job
d. I am formally self-employed
e. I am informally self-employed
f. I am retired

6. With whom do you live? Please select only one option
a. With partner
b. With partner and children

7. If children are present at home, please detail number and ages:

8. Before lockdown, did you rely on external help for housework and childcare?
9. Before lockdown, the main income in the household was provided by:
a. You?
b. Your partner?
c. Other?:

10. During lockdown, the main income in the household was provided by:
a. You?
b. Your partner?
c. Other?:

\section{Section B. Information on Time-Use}

11. Information on your own time-use

\begin{tabular}{|c|c|}
\hline $\begin{array}{l}\text { How much time did you allo- } \\
\text { cate to each of these activi- } \\
\text { ties BEFORE lockdown? } \\
\text { Please think of a typical day } \\
\text { (from Monday to Friday) }\end{array}$ & $\begin{array}{l}\text { How much time did you allo- } \\
\text { cate to each of these activities } \\
\text { DURING lockdown? Please } \\
\text { think of a typical day (from } \\
\text { Monday to Friday) }\end{array}$ \\
\hline Time & Time \\
\hline Paid Work & Paid Work \\
\hline $\begin{array}{l}\text { Domestic chores in your own } \\
\text { house (cooking, cleaning, } \\
\text { ironing, etc.) }\end{array}$ & $\begin{array}{l}\text { Domestic chores in your own } \\
\text { house (cooking, cleaning, } \\
\text { ironing, etc.) }\end{array}$ \\
\hline $\begin{array}{l}\text { Childcare in your own house } \\
\text { (caring, playing, feeding) }\end{array}$ & $\begin{array}{l}\text { Childcare in your own house } \\
\text { (caring, playing, feeding) }\end{array}$ \\
\hline $\begin{array}{l}\text { Educational childcare (help } \\
\text { with homeschooling) }\end{array}$ & $\begin{array}{l}\text { Educational childcare (help } \\
\text { with homeschooling) }\end{array}$ \\
\hline $\begin{array}{l}\text { Leisure (sports, films, books, } \\
\text { etc.) }\end{array}$ & $\begin{array}{l}\text { Leisure (sports, films, books, } \\
\text { etc.) }\end{array}$ \\
\hline
\end{tabular}

12. Information on your partner's time

\begin{tabular}{|c|c|}
\hline $\begin{array}{l}\text { How much time did your } \\
\text { partner allocate to each of } \\
\text { these activities BEFORE } \\
\text { lockdown? Please think of } \\
\text { a typical day (from Monday } \\
\text { to Friday) }\end{array}$ & $\begin{array}{l}\text { How much time did your } \\
\text { partner allocate to each of } \\
\text { these activities DURING } \\
\text { lockdown? Please think of a } \\
\text { typical day (from Monday to } \\
\text { Friday) }\end{array}$ \\
\hline Time & Time \\
\hline Paid Work & Paid Work \\
\hline $\begin{array}{l}\text { Domestic chores in } \\
\text { your own house } \\
\text { (cooking, cleaning, } \\
\text { ironing, etc.) }\end{array}$ & $\begin{array}{l}\text { Domestic chores in } \\
\text { your own house } \\
\text { (cooking, cleaning, } \\
\text { ironing, etc.) }\end{array}$ \\
\hline
\end{tabular}




\begin{tabular}{lll}
\hline & Time & Time \\
Paid Work & Paid Work & \\
\hline Childcare in your & Childcare in your own \\
own house (caring, & house (caring, play- \\
playing, feeding) & ing, feeding) \\
Educational childcare & Educational childcare \\
(help with home- & (help with home- \\
schooling) & schooling) \\
Leisure (sports, films, & Leisure (sports, films, \\
books, etc.) & books, etc.) \\
\hline
\end{tabular}

\section{Section C. Perceptions (To be Answered Only by Those Working Before Lockdown)}

13. How much do you identify with these expressions?:

a. Combining housework/childcare and work was difficult before lockdown

b. Combining housework/childcare and work has become more difficult during lockdown.

c. During lockdown, I have to interrupt my work often to attend to domestic matters.

\section{Appendix B}

Table B.1 Comparison of key socio-demographic variables with the Argentinean Time Use Survey (INDEC)

\begin{tabular}{lcc}
\hline & Sample & INDEC \\
\hline Couples with children & $81.7 \%$ & $75.5 \%$ \\
Couples without children & $18.3 \%$ & $24.5 \%$ \\
Low income households & $48.2 \%$ & $44.4 \%$ \\
Middle income households & $13.1 \%$ & $19.3 \%$ \\
High income households & $38.7 \%$ & $36.3 \%$ \\
Families with 1 child & $32.1 \%$ & $35.5 \%$ \\
Families with 2 children & $33.1 \%$ & $36.1 \%$ \\
Families with 3 children & $23.1 \%$ & $16.8 \%$ \\
Families with + 3 children & $11.7 \%$ & $11.6 \%$ \\
Average number of children & 2.2 & 2.1 \\
Northern Region & $9.58 \%$ & $16.3 \%$ \\
Central Region & $70.1 \%$ & $69.3 \%$ \\
Buenos Aires City & $15.4 \%$ & $8.9 \%$ \\
Southern Region & $4.9 \%$ & $5.5 \%$ \\
Woman's Age & 40.3 & 45.1 \\
Woman has primary education & $9.6 \%$ & $31.9 \%$ \\
Woman has secondary education & $44.0 \%$ & $40.0 \%$ \\
Woman has high education & $46.4 \%$ & $28.1 \%$ \\
Man is employed & $80.3 \%$ & $76.5 \%$ \\
Woman is employed & $58.5 \%$ & $42.7 \%$ \\
Hours of paid work per week - man & 39.51 & 40.25 \\
Hours of paid work per week - woman & 28.52 & 17.59 \\
Hours of housework per day - man & 1.62 & 1.16 \\
Hours of housework per day - woman & 3.73 & 4.37 \\
Hours of childcare per day - man & 1.83 & 1.12 \\
Hours of childcare per day - woman & 4.33 & 3.02 \\
Hours of educational childcare per day - man & 1.04 & 0.23 \\
Hours of educational childcare per day - woman & 2.48 & 0.71 \\
\hline & & \\
& &
\end{tabular}

Reference population values and shares are drawn from the nationally representative Time Use Survey 2013 implemented by the National Statistics Office in Argentina (INDEC). Low (high) income families are those belonging to the lowest (upper) two quintiles of the national income distribution. Income quintiles were defined according to the Argentinean Time Use Survey. Time use questions of the National Survey are slightly different from time use questions in our survey in terms of activities included and the typical day of reference (see https://www.indec.gob.ar/ftp/cuadros/menusuperior/tnr/Cuestionario_ TNR.pdf). 
Table B.2 Regressions on within-couple gender gap changes. Full set of estimates

\begin{tabular}{|c|c|c|c|}
\hline & Housework & Childcare & $\begin{array}{l}\text { Educational } \\
\text { childcare }\end{array}$ \\
\hline Man and woman working & $\begin{array}{l}0.014 \\
(0.221)\end{array}$ & $\begin{array}{l}-0.310 \\
(0.259)\end{array}$ & $\begin{array}{l}-0.400^{\dagger} \\
(0.207)\end{array}$ \\
\hline Working from home-woman & $\begin{array}{l}0.220 \\
(0.258)\end{array}$ & $\begin{array}{l}0.645^{*} \\
(0.316)\end{array}$ & $\begin{array}{l}0.697 * * \\
(0.252)\end{array}$ \\
\hline Change in hours of work-man & $\begin{array}{l}0.057^{\dagger} \\
(0.029)\end{array}$ & $\begin{array}{l}0.086^{*} \\
(0.034)\end{array}$ & $\begin{array}{l}0.055^{*} \\
(0.027)\end{array}$ \\
\hline Change in hours of work-woman & $\begin{array}{l}-0.102^{* *} \\
(0.033)\end{array}$ & $\begin{array}{l}-0.093^{*} \\
(0.039)\end{array}$ & $\begin{array}{l}-0.068^{*} \\
(0.031)\end{array}$ \\
\hline From home $*$ change hs. - woman & $\begin{array}{l}0.001 \\
(0.0640)\end{array}$ & $\begin{array}{l}-0.118 \\
(0.075)\end{array}$ & $\begin{array}{l}-0.022 \\
(0.060)\end{array}$ \\
\hline Domestic Employee & $\begin{array}{l}0.450^{\dagger} \\
(0.257)\end{array}$ & $\begin{array}{l}-0.078 \\
(0.315)\end{array}$ & $\begin{array}{l}0.400 \\
(0.251)\end{array}$ \\
\hline Woman has primary education & $\begin{array}{l}0.00673 \\
(0.384)\end{array}$ & $\begin{array}{l}0.648 \\
(0.464)\end{array}$ & $\begin{array}{l}0.283 \\
(0.370)\end{array}$ \\
\hline Woman has secondary education & $\begin{array}{l}-0.274 \\
(0.257)\end{array}$ & $\begin{array}{l}0.236 \\
(0.319)\end{array}$ & $\begin{array}{l}0.023 \\
(0.254)\end{array}$ \\
\hline Woman's age & $\begin{array}{l}-0.002 \\
(0.009)\end{array}$ & $\begin{array}{l}-0.013 \\
(0.013)\end{array}$ & $\begin{array}{l}-0.020 * \\
(0.0101)\end{array}$ \\
\hline Low income family & $\begin{array}{l}-0.204 \\
(0.251)\end{array}$ & $\begin{array}{l}-0.440 \\
(0.303)\end{array}$ & $\begin{array}{l}-0.511^{*} \\
(0.241)\end{array}$ \\
\hline Number of children in the family & $\begin{array}{l}0.124^{\dagger} \\
(0.073)\end{array}$ & $\begin{array}{l}0.0413 \\
(0.104)\end{array}$ & $\begin{array}{l}0.189 * \\
(0.0830)\end{array}$ \\
\hline Northern Region & $\begin{array}{l}-0.678^{\dagger} \\
(0.386)\end{array}$ & $\begin{array}{l}-0.366 \\
(0.460)\end{array}$ & $\begin{array}{l}-0.058 \\
(0.367)\end{array}$ \\
\hline Central and Southern Regions & $\begin{array}{l}-0.090 \\
(0.262)\end{array}$ & $\begin{array}{l}-0.498 \\
(0.317)\end{array}$ & $\begin{array}{l}0.046 \\
(0.253)\end{array}$ \\
\hline Constant & $\begin{array}{l}0.337 \\
(0.553)\end{array}$ & $\begin{array}{l}1.037 \\
(0.740)\end{array}$ & $\begin{array}{l}1.044^{\dagger} \\
(0.590)\end{array}$ \\
\hline Observations & 961 & 785 & 785 \\
\hline R-squared & 0.040 & 0.048 & 0.063 \\
\hline
\end{tabular}

"Housework" is the within-couple gender gap change in hours allocated to housework; "Childcare" is the within-couple gender gap change in hours allocated to childcare; "Educational Childcare" is the within-couple gender gap change in hours allocated to educational support. All changes compare the within-couple gender gaps before and during lockdown. Within-couple gender gaps are defined as hours allocated to the activity by the woman minus hours allocated to the same activity by the man. For "Housework" all couples are included, for "Childcare" and "Educational Childcare" only couples with children are included. Standard errors in parenthesis.

$\dagger \mathrm{p}<0.1, * \mathrm{p}<0.05, * * \mathrm{p}<0.01$ 
Table B.3 Regressions on within-couple gender gap changes using post-stratification weights

\begin{tabular}{|c|c|c|c|}
\hline & Housework & Childcare & Educational childcare \\
\hline Man and woman working & $\begin{array}{l}0.498 \\
(0.321)\end{array}$ & $\begin{array}{l}0.189 \\
(0.316)\end{array}$ & $\begin{array}{l}-0.475^{\dagger} \\
(0.263)\end{array}$ \\
\hline Working from home-woman & $\begin{array}{l}-0.119 \\
(0.312)\end{array}$ & $\begin{array}{l}0.699^{\dagger} \\
(0.406)\end{array}$ & $\begin{array}{l}0.849 * * \\
(0.292)\end{array}$ \\
\hline Change in hours of work-man & $\begin{array}{l}-0.014 \\
(0.054)\end{array}$ & $\begin{array}{l}0.039 \\
(0.044)\end{array}$ & $\begin{array}{l}0.0343 \\
(0.045)\end{array}$ \\
\hline Change in hours of work-woman & $\begin{array}{l}-0.092^{\dagger} \\
(0.051)\end{array}$ & $\begin{array}{l}-0.095^{\dagger} \\
(0.053)\end{array}$ & $\begin{array}{c}-0.063 \\
(0.056)\end{array}$ \\
\hline From home $*$ change hs.—woman & $\begin{array}{l}-0.021 \\
(0.076)\end{array}$ & $\begin{array}{l}-0.126 \\
(0.095)\end{array}$ & $\begin{array}{l}-0.022 \\
(0.087)\end{array}$ \\
\hline Domestic Employee & $\begin{array}{l}0.344 \\
(0.329)\end{array}$ & $\begin{array}{l}-0.179 \\
(0.284)\end{array}$ & $\begin{array}{l}0.133 \\
(0.248)\end{array}$ \\
\hline Woman has primary education & $\begin{array}{l}0.544 \\
(0.449)\end{array}$ & $\begin{array}{l}0.626 \\
(0.462)\end{array}$ & $\begin{array}{l}-0.161 \\
(0.346)\end{array}$ \\
\hline Woman has secondary education & $\begin{array}{l}-0.142 \\
(0.328)\end{array}$ & $\begin{array}{l}0.360 \\
(0.379)\end{array}$ & $\begin{array}{l}-0.192 \\
(0.304)\end{array}$ \\
\hline Woman's age & $\begin{array}{l}0.003 \\
(0.012)\end{array}$ & $\begin{array}{l}-0.016 \\
(0.015)\end{array}$ & $\begin{array}{l}-0.026^{* *} \\
(0.010)\end{array}$ \\
\hline Low income family & $\begin{array}{l}-0.666^{\dagger} \\
(0.348)\end{array}$ & $\begin{array}{l}-0.448 \\
(0.362)\end{array}$ & $\begin{array}{l}-0.314 \\
(0.278)\end{array}$ \\
\hline Number of children in the family & $\begin{array}{l}0.126 \\
(0.108)\end{array}$ & $\begin{array}{l}-0.024 \\
(0.138)\end{array}$ & $\begin{array}{l}0.114 \\
(0.117)\end{array}$ \\
\hline Northern Region & $\begin{array}{l}-0.365 \\
(0.503)\end{array}$ & $\begin{array}{l}-0.490 \\
(0.479)\end{array}$ & $\begin{array}{l}0.254 \\
(0.432)\end{array}$ \\
\hline Central and Southern Regions & $\begin{array}{l}-0.396 \\
(0.371)\end{array}$ & $\begin{array}{l}-0.157 \\
(0.331)\end{array}$ & $\begin{array}{l}0.449^{\dagger} \\
(0.266)\end{array}$ \\
\hline Constant & $\begin{array}{l}0.144 \\
(0.702)\end{array}$ & $\begin{array}{l}0.664 \\
(0.951)\end{array}$ & $\begin{array}{l}1.256^{*} \\
(0.580)\end{array}$ \\
\hline Observations & 961 & 785 & 785 \\
\hline R-squared & 0.039 & 0.044 & 0.052 \\
\hline
\end{tabular}

Regressions are weighted using post-stratification weights based on national values of key socio-demographic variables (level of education of the woman, income quintile, presence of children and region of residence). National values are obtained from the Argentinean Time Use Survey (INDEC). "Housework" is the within-couple gender gap change in hours allocated to housework; "Childcare" is the within-couple gender gap change in hours allocated to childcare; "Educational Childcare" is the within-couple gender gap change in hours allocated to educational support. All changes compare the within-couple gender gaps before and during lockdown. Within-couple gender gaps are defined as hours allocated to the activity by the woman minus hours allocated to the same activity by the man. For "Housework" all couples are included, for "Childcare" and "Educational Childcare" only couples with children are included. Standard errors in parenthesis.

$\dagger \mathrm{p}<0.1, * \mathrm{p}<0.05, * * \mathrm{p}<0.01$.
Funding Funding was provided by the CEDH-San Andres University, Argentina.

Data Availability Data analysis was carried out using the statistical software STATA. Data and code are all available at: https://www.dropb ox.com/sh/n0b92k1ynedq31j/AACSS6WrtiDhAaZzE_IzTwI_a?dl=0

\section{Declarations}

\section{Conflict of interest None.}

\section{References}

Adams-Prassl, A., Boneva, T., Golin, M., \& Rauh, C. (2020). Inequality in the impact of the coronavirus shock: evidence from real time surveys. Journal of Public Economics, 189, 104-245. https://doi. org/10.1016/j.jpubeco.2020.104245/

Alon, T. M., Doepke, M., Olmstead-Rumsey, J., \& Tertilt, M. (2020a). The impact of Covid-19 on gender equality. Covid Economics: Vetted and Real-Time Papers Issue, 4(62), 85. https://doi.org/10. 3386/w26947/ 
Alon, T. M., Kim, M., Lagakos, D., \& VanVuren, M. (2020). How should policy responses to the Covid-19 pandemic differ in the developing world? (NBER Working Paper 27273). National Bureau of Economic Research. https://doi.org/10.3386/w27273/

Andrew, A., Cattan, S., Dias, M. C., Farquharson, C., Kraftman, L., Krutikova, S., \& Sevilla, A. (2020). How are mothers and fathers balancing work and family under lockdown? (Institute for Fiscal Studies Briefing Note 290). Institute for the Fiscal Studies. https:// doi.org/10.1920/bn.ifs.2020.bn0290/

Angelov, N., Johansson, P., \& Lindahl, E. (2016). Parenthood and the gender gap in pay. Journal of Labor Economics, 34(3), 545-579

Berniell, I., Berniell, L., De la Mata, D., Edo, M., \& Marchionni, M. (2019). Gender gaps in labor informality: the motherhood effect. Journal of Economic Development. https://doi.org/10.1016/j.jdeve co.2020.102599/

Bertrand, M. (2020). Gender in the twenty-first century. AEA Papers and Proceedings, 110, 1-24. https://doi.org/10.1257/pandp.20201 126

Biroli, P., Bosworth, S., Della Giusta, M., Di Girolamo, A., Jaworska, S. \& Vollen, J. (2020). Family life in lockdown (IZA Discussion Paper 13398). IZA.

Blau, F., \& Kahn, L. (2006). The U.S. gender pay gap in the 1990s: slowing convergence. Industrial and Labor Relations Review, 60(1), 45-66. https://doi.org/10.3386/w10853/

Campaña, J. C., Giménez-Nadal, J. I., \& Molina, J. A. (2018). Gender norms and the gendered distribution of total work in Latin American households. Feminist Economics, 24(1), 35-62. https://doi.org/10.1080/13545701.2017.1390320/

Canelas, C., \& Salazar, S. (2014). Gender and ethnic inequalities in LAC countries. IZA Journal of Labor \& Development, 3(1), 18. https://doi.org/10.1186/2193-9020-3-18/

Carlson, D., Petts, R. \& Pepin, J. (2020). Men and women agree: during the Covid-19 pandemic men are doing more at home. CCF News Brief Reports. https://contemporaryfamilies.org/ covid-couples-division-of-labor/.

Carreras, E., Gibbons, M. A., Murphy, T. E., Perez-Vincent, S. M., \& Rossi, M. (2020). Covid-19 lockdowns and domestic violence evidence from two studies in Argentina (IDB Technical Note 1956). International Development Bank. https://doi.org/10.18235/00024 90/

Chioda, L. (2016). Work and family. Latin American and Caribbean women in search of balance. Washington: World Bank.

Del Boca, D. D., Oggero, N., Profeta, P., \& Rossi, M. (2020). Women's work, housework and childcare, before and during COVID-19. Review of Economics of the Household. https://doi.org/10.1007/ s11150-020-09502-1/

Dobrée, P. \& Cora, C. (2020). Aplanemos también la curva de los cuidados. Centro de Documentación y Estudios (CDE). https:// www.cde.org.py/tiempodecoronavirus/2020/03/31/aplanemostambien-la-curva-de-los-cuidados/.

ECLAC (2019). Women's autonomy in changing economic scenarios. Comisión Económica para América Latina y el Caribe (CEPAL).

ECLAC (2020). The COVID-19 pandemic is exacerbating the care crisis in Latin America and the Caribbean. Comisión Económica para América Latina y el Caribe (CEPAL).

Farré, L., Fawaz, Y., González, L. \& Graves, J. (2020). How the COVID-19 lockdown affected gender inequality in paid and unpaid work in Spain (IZA Discussion Paper 13434). IZA.

Galasso, V., Pons, V., Profeta, P., Becher, M., Brouard, S., \& Foucault, M. (2020). Gender differences in Covid-19 related attitudes and behavior: evidence from a panel survey in eight OECD countries (NBER Working Paper 27359). National Bureau of Economic Research. https://doi.org/10.3386/w27359/
Giménez-Nadal, J. I., Molina, J. A. \& Velilla, J. (2020). Should we cheer together? Gender differences in instantaneous well-being during joint and solo activities: An application to COVID-19 lockdowns (GLO Discussion Paper 736). Global Labor Organization.

Goldin, C. (2006). The quiet revolution that transformed women's employment, education, and family. AEA Papers and Proceedings, 96(2), 1-21. https://doi.org/10.3386/w11953/

Goldin, C. (2014). A Grand Gender Convergence: Its Last Chapter. American Economic Review, 104(4), 1091-1119. https://doi.org/ 10.1257/aer.104.4.1091/

Hale, T., Webster, S., Petherick, A., Phillips, T. \& Kira, B. (2020). Oxford Covid-19 government response tracker.

Hamermesh, D. S. (2020). Life satisfaction, loneliness and togetherness, with an application to Covid-19 lock-downs. Review of Economics of the Household, 18, 983-1000. https://doi.org/10.1007/ s11150-020-09495-x/

Hupkau, C., \& Petrolongo, B. (2020). Work, care and gender during the Covid-19 crisis (IZA Discussion Paper 13762). IZA. https:// doi.org/10.1111/1475-5890.12245/

INDEC (2020). Hacia la encuesta nacional sobre uso del tiempo y trabajo no remunerado (INDEC Working Paper 30). Instituto Nacional de Estadística y Censos Argentina.

Kan, M. Y., \& Pudney, S. (2008). Measurement error in stylized and diary data on time use. Sociological Methoodology, 38(1), 101132. https://doi.org/10.1111/j.1467-9531.2008.00197.x/

Kleven, H., Landais, C., Søgaard, J., \& E. . (2019). Children and gender inequality: evidence from Denmark. American Economic Journal: Applied Economics, 11(4), 181-209. https://doi.org/10.3386/ w24219/

Kuziemko, I., Pan, J., Shen, J., \& Washington, E. (2018). The mommy effect: do women anticipate the employment effects of motherhood? (NBER Working Paper). National Bureau of Economic Research. https://doi.org/10.3386/w24740/

Mangiavacchi, L., Piccoli, L. \& Pieroni, L. (2020). Fathers matter: intra-household responsibilities and children's wellbeing during the Covid-19 lockdown in Italy (IZA Working Paper 13519). IZA.

Marchionni, M., Gasparini, L., \& Edo, M. (2019). Brechas de género en América Latina, un estado de situación. Caracas: CAF.

Romero, T. H., \& Reys, A. (2020). Empobrecimiento de los hogares y cambios en el abastecimiento de alimentos por la COVID-19 en Lima, Perú. Revista de Recursos en Internet sobre Geografía y Ciencias Sociales. https://doi.org/10.1344/ara2020.243.31627/

Sevilla, A., \& Smith, S. (2020). Baby steps: the gender division of childcare during the COVID19 pandemic. Oxford Review of Economic Policy, 36(S1), S169-S186. https://doi.org/10.1093/oxrep/ graa027/

Wanderley, F., Losantos, M., Tito, C. \& Arias, A. M. (2020). Los impactos sociales y psicológicos del COVID-19 en Bolivia. Serie Reflexiones sobre la Pandemia en Bolivia, No 3.

UN Women, UNICEF \& Option Consultants. (2020). Survey on childhood, gender and time use in the context of the health emergency. United Nations. https://lac.unwomen.org/es/digiteca/publicacio nes/2020/06/encuesta-ninez-genero-y-uso-de-tiempo-uruguay/.

Zhou, M., Hertog, E., Kolpashnikova, K. \& Kan, M., Y. (2020). Gender inequalities: changes in income, time use and well-being before and during the UK COVID-19 lockdown. Department of Sociology, University of Oxford. https://doi.org/10.31235/osf.io/u8ytc/.

Publisher's Note Springer Nature remains neutral with regard to jurisdictional claims in published maps and institutional affiliations. 